-----J. Raf. Sci., Vol. 20, No.2, pp 37- 41, 2009-----

\title{
and Copper Levels in Seropositive Toxoplasmosis Women in Mosul - Iraq
}

\author{
Elham M. Al-Khshab \\ Department of Physiology \\ Haitham S. Al-Bakry \\ College of Veterinary Medicine \\ Mosul University
}

(Received 3/11/2008; Accepted 26/1/2009)

\begin{abstract}
The aim of this Study was to investigate the effects of Toxoplasma gondii infection on levels of zinc and copper in seropositive toxoplasmosis women in Mosul city. Serum zinc and copper levels were measured in (77) women whose -Toxoplasma gondii antibodies were Positive , in addition to (30) sero - negative healthy women, as control group. The average zinc concentration in serum from sero - positive women was significantly $(\mathrm{P}<0.05)$ lower than control group. Howevor compared to the healthy women , the copper concentration in serum of sero-positive women were significantly $(\mathrm{P}<0.05)$ higher.
\end{abstract}

Key word : Zinc, Copper, toxoplasmosis

\section{مستوبل الزك والنحس في النساء المصلبلت بداء النالاف الموطل - العرق}

\section{الملغص}

الغرض من الدرلسة هومعرفة تأثير الإصابة بطفيلي المقوست الكوندي ـة ف مي مـ ستويك الزن لك

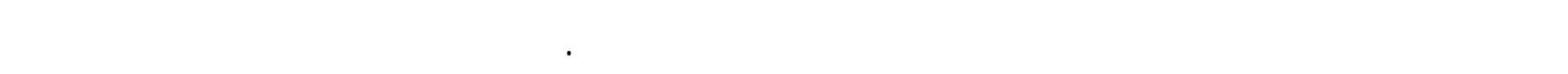

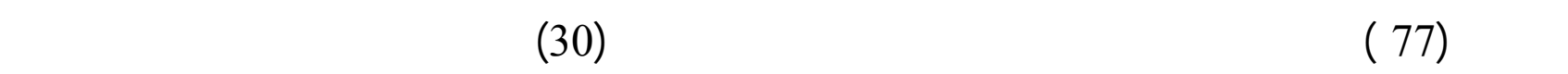

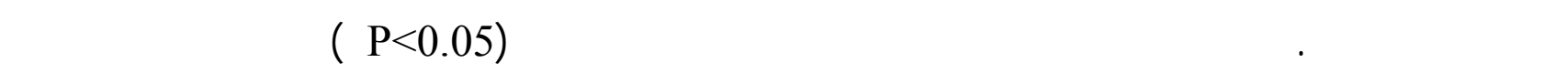

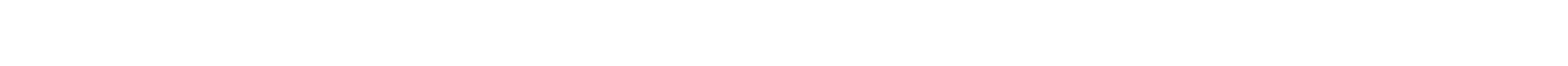
معنوي(P<0.05) في أمصل النساء المصابلت مقارنة بللسطيطرة .

\section{INTRODUCTION}

Trace elements are essential for normal growth and development of skeleton and they play important roles in biological systems by participation in structures or as active sites of metaloenzymes. Excess or deficiency causes alterations in respective serum level. Many Phathological conditions such as bronchitis, Pneumonia, Psoriasis, rheumatic heart failure, hemolytic anemia and other infectious diseases result in alteration of the trace elements levels in blood and other tissues (El-Kholy et al., 1990 ). 
Zinc is an element of widespread occurrence within the earth's crust (Thomas, 1998 ). It is essential for protein synthesis (Standstead et al., 2000 ), for immune function , that plays a role immune response a gainst parasites (Wellinghausen et al., 1999 ) and it has many effects on function of same hormones like TSH, GH, LH and FSH (Tudor et al., 2005).

Copper . is a trace element known as a cofactor for many enzymes (Swaminthan , 1999). It is integral part of cytochrome (Griffiths and Wharton , 1961) and it Localized in liver, brain, Kidney and heart and it has role in hemoglobin production (Kazat et al., 2006).

Toxoplasmosis is a disease caused by Toxoplasma gondii (Ryan and Ray , 2004 ) Which is obligate intracellur protozoan Parasite, it is a World - Wide Zoonosis of increasing concerning both human and Veterinary Medicine, it is known to cause transplacental infections that can lead to abortion or sever neonatal malformation (Remington and Desmont , 1983 ). The natural host of Toxoplasma gondii is the cat , however it also occurs by chance in humans, a large group of domestic mammals (dog , swine, sheep, cattle, goats ), certain rodents some birds and a few other animals (Torda, 2001), While this is true, contact with infected raw meat is perhaps a more important cause of human infection in many third world countries. Up to third of the worlds population is estimated to carry a Toxoplasma infection (Montaya and Liesenfeld , 2004). The disease can be transmitted by ingestion of oocyst ( in cat feces) or bradyzoites (in raw or under cooked ) ( Montaya, 2002 , Tenter et al., 2000). However under some conditions, toxoplasmosis can cause serious diseases or infections, including blindness, Pneumonia, hepatitis and sever neurological disorders in patients with human immuno deficiencyVirus (H I V) (Frankel, 1988 ).

\section{MATERIALS AND METHODS}

The Study was carried out on (77) serum - smaples taken from Toxoplasmosis women ( acute case) and 30 samples taken from women who showed negative result for serum - Toxoplasmosis (control group ). All these women aged $(19-42)$ years and attending Central Laboratory in Mosul City. Non of toxoplasmosis women and control group were taken any medication or trace elements supplementation.

Serological test was done Using Latex Agglutination with Toxo-cell-Latex Kit (Bio Kit - Span).

Serum samples were collected in plane tube and frozen at $\left(-20^{\circ} \mathrm{C}\right)$ until needed for determination of zinc and copper. Atomic absorption spectrophotometry was used to determine Zinc and copper in seum, the procedure involved a simple sample dilution with deionized water (D’Haese et al., 1992). The analysis was performed a gainst standards prepared in glycerol to match the viscosity of the diluted samples (1:5)

Reagents for zinc determination

Glycerol 5\% ( V/V)

Zinc metal

Hydrochloric acid, diluted ( $1+1)$ with deionized water

Reagents for copper determination

Glycerol 10\% ( V/V)

Copper metal

Nitric acid, diluted ( $1+1)$ with deionized water 


\section{RESULTS AND DISCUSSION}

The results in table 1 refer to the levels of zinc and copper in seropositive toxoplasmosis women. The mean levels of serum zinc were significantly $(\mathrm{P}<0.05)$ lower than in control group, while serum copper concentration were significantly $(\mathrm{P}<0.05)$ higher. These results agree with (Ageel, 2003 ; seyerk et al., 2004 ) they were noted a reduction in serum zinc in human and animals. This mean zinc necessary for immune function and play a role in immune response against parasites (klassing , 1984). The role of certain inflammatory products in regulation of the zinc balance has been well documented. Thus, leukocyte endogenous mediators ( interleukins), released from activated phagocytic cells causing a lowering of zinc levels resulting from increased synthesis of metalothionine in liver and other tissues (Klassing, 1988 ; Svenson et al., 1985). Also zinc deficient animals have suppressed immune responses and are more susceptible to a diverse range of infectious agents including Herpes simplex virus (Feiler et al., 1982). Listeria monocytogenes (Coghlan et al., 1988).

Toxoplasma gondii (Tasci et al., 1995) Trypanosoma musculi (Lee et al., 1983). In study carried out on rats experimentally infected with toxoplasmosis, showed that, intraperitoneal injections of zinc sulfate at a dose of $3 \mathrm{mg} / \mathrm{kg}$ for 3 weeks , stimulating CD4 and CD8 + production and may activate cellular immunity (Avunduk et al., 2007). Zinc status may also affect placental transport of antibodies from the mother to the fetus during the last trimester of pregnancy. Because zinc is important for normal placental development , deficiency may result in impairetment in utero a cquisition of maternal antibodies by the child as well (Seyoum and Persaud ,1995). Therefore one of the potential beneficial approaches to improve the immune defense against $T$. gondii is zinc supplementation, since due to its catalytic and regulatory functions it can enhance resistance to infections (Mocchegiani et al., 2001).

Table 1 : Comparision between seropositive toxoplasmosis women and control group in serum zinc and copper levels .

\begin{tabular}{|c|c|c|c|}
\hline Parameter & $\begin{array}{c}\text { Control group } \\
\mathbf{n = 3 0} \\
\text { mean + SD }\end{array}$ & $\begin{array}{c}\text { Seropositive toxoplasmosis women } \\
\mathbf{n = 7 7} \\
\text { mean + SD }\end{array}$ & P-Value \\
\hline $\begin{array}{c}\text { Zinc } \\
\mu \mathrm{mol} / \mathrm{L}\end{array}$ & $13.5 \pm 3.0$ & $12.1 \pm 5.6$ & $<0.05$ \\
\hline $\begin{array}{c}\text { Copper } \\
\mu \mathrm{mol} / \mathrm{L}\end{array}$ & $19.2 \pm 4.8$ & $20.3 \pm 4.5$ & $<0.05$ \\
\hline
\end{tabular}

In contrasts, increase serum copper in toxoplasmosis women may be due to the increased production of the carring protein ceruplasmine, by zinc - dependent process, copper stores may become depleted (Mclaren - Howard and Grant, 1998). Our study agree with (Seyerk et al.,2004) they noted an increase in copper concentration in sheep infected with Toxoplasmosis because the active phase of interleukins that causes increasing in copper concentration . Also our results agree with (Al- Zuhairy , 2008) who pointed to the elevation in serum copper in sheep infected with Toxoplasmosis and attributed this result to 
ceruplasmine level that formed in response to inflammation associated with the disease. This study conclusioned, that zinc should be considered as adjunctive therapy to treatment Toxoplasma . In patients with HIV, zinc deficiency is frequently seen by decrease zinc serum concentrations and depressed phytohemagglutinin ( PHA) mitogenic responses. These changes are partially reversible by zinc supplementation .

\section{REFERENCES}

Ageel, N. F. M., 2003. Serological and Biochemistry Study of Toxoplasmosis in Tikrit Teaching Hospital . M. Sc thesis College of Medicine, University of Tikrit, Iraq .

AL - Zuhairy, A. S. M., 2008. Some Biochemical Parameters in Sheep Infected with Toxoplasmosis . M. Sc thesis College of Medicine, University of Mosul . Iraq .

Avunduk , A. M.; Avunduk, M. C.; Baltaci , A. K. and Mustafa, C. A., 2007. Effect of Melatonin and Zinc on the Immune Response in Experimental Toxoplasma Retinochoroiditis . Ophthalmologica; 221 : pp. $421-425$.

Coghlan, I. G.; Carlomagno, M. A. and MeMurray, D. N., 1988. Effect of Protein and Zinc Deficiencies on Vaccine Afficacy in Guinea Pigs Following Pulmonary Infection with Listeria ; Med. Microbiol . Immunol ; 177: pp. 63- 255.

D’ Haese, P. C.; Lamberts , L. V.; Vanheule, A. O. and De Broe , M. E., 1992. Direct Determination of Zinc in Serum by Zeeman Atomic Absorption Spectrometry with a Graphite Furnace . Clin . Chem .,38 (12): pp. 2439 - 2443 .

El - Kholy, S. M.; GAB - Allah, A. M. and El - Shimi, S. J., 1990. Serum Zinc and Copper Status in Children with Bronchial Asthma and Atopic Dermatitis. J. Egypt Pub Health Assoc., 65 ( $5-6$ ): pp. $557-668$.

Feiler, L. S.; Smdin , G.; Okumoto , M. and Condon , D., 1982. Herpetic keratitis in Zinc Deficient rabbits . Invest . Opthalmol . Vis . Sci., 22 : pp. 95- 788.

Frankel, K. J., 1988. Physiopathology of Toxoplasmosis . Parasitol ., 4: pp. $273-278$.

Griffiths, E. D. and Wharton, C. D., 1961 . Studies of the Electron Transport System . J. Biol Chem ., 236 : pp. $1850-1856$.

Kazat, S.; Yukeseke , N.; Goz, Y. and Keles, I., 2006. Serum Iron, Total iron - Binding Capacity, Unbound Iron - Binding Capacity Transferrin Satuation, Serum Copper and Hematological Parameters in Pregn AK Karaman Ewes Infected with Gastrointestinal Parasites, Turk . J. Vet . Anim . Sci ., 30: pp. $601-604$.

Klassing, C. K., 1984. Effect of Inflammatory Agents and Interleukin I on Iron and Zinc Metabolism. Am. J. Physiol ., 247 : pp. $901-904$.

Klassing , C. K. 1988. Nutritional Aspects of luekocytic Cytokins . J. Nut. 118 : pp. $1435-1443$.

Lee, C. M.; Humphrey , P. A. and Abokocole , G. E. ,1983. Interaction of Nutrition and Infection: Effect of Zinc Defficiency on Resistance to Trypanosoma Musculi . Int. J. Biochem ; 15: pp. 7- 841.

Mclaren - Howard, J. and Grant, E. C., 1998. Osteoporosis : Bone Enzymes and Nutrient Imbalances . J.Nutr . Environ . Med ; 8 (2) : pp. 2, 10,129.

Mocchegiani, E.; Giacconi , R. and Muzzioli , R., 2001 . Zinc , Infections and Immunosenescence .Mech . Aging . Dev. ; 121 : pp. $21-35$. 
Montaya, J. and Liesenfeld , O., 2004. " Toxoplasmosis " Lacent ; 363 (19425). pp.76-1965.

Montaya, J., 2002. Laboratory Diagnosis of Toxoplasma gondii Infection and Toxoplasmosis .J. Infect Dis ; 185 (15) : pp. 78 - 82 .

Remington, J. S. and Desmont, G. G., 1983. In: Infectionous Disease of the Fetus and Newborn Infant, eds., Remngton, J.S., Saunders, Philadelphia, pp. 143 - 161 .

Ryan, K. J. and Ray , C. G., 2004. Sherris Medical Microbiology, 4th Edn ., Mc Graw Hill, $7237 \mathrm{p}$.

Seyerk, K.; Pasa, S.; Kiral, F.; Bildik , A.; Babur , C. and Kilic, S., 2004. Levels of Zinc, Copper and Magnesium in Sheep with Toxoplasmosis, Uludag. Univ . J. Fac . Vet. Med., 23: pp. $39-42$.

Seyoum, G. and Persaud, T. V., 1995. Influence of Zinc on Ethanol - Induced Placental Changes in the Rat . Histol . Histopathol. ; 10: pp. 25-117.

Standstead, H. H.; Frederickson, C. J. and Panland, J. G., 2000. Zinc Development and Function of the Brain. J. Trace . Microprobe . Techniq ., 18 (4) : pp. $517-521$.

Svenson, KLG.; Hallgren , R.; Johansen , E. and Lindth , U., 1985. Reduced Zinc in Peripheral Blood Cells from Patients with Inflammatory Connective Tissue Disease. Inflammation ; 9 : pp. 189 - 199.

Swaminathan , R., 1999. Nutritional Factors in Osteoporosis. Int. J. Clin. Pract .,53(7): pp. $540-548$.

Tasci, S.; Sengil , A. Z.; Altindis , M. and Arisoy , K., 1995. The Effect of Zinc Supplementation in Experimentally Induced Toxoplasma gondii Infection. J. Egypt . Soc. Parasitol ; 25 : pp. $745-755$.

Tenter, A. M.; Heckeroth , A. R. and Weiss , L. M., 2000. Toxoplasma gondii : from Animals to Humans. Int. J. Parasitol ., 30 ( $12-13$ ): pp.1217 - 1258 .

Thomas, L., 1998. Clinical laboratory diagnostic . 1st Edn., TH - Books, Frankfurt, Main Germany .

Torda, A., 2001. Toxoplasmosis. Are Cats Really the Source? Aust Fam Pysican. 30 (8): pp $.7-743$

Tudor, R.; Zalewski , P. D. and Ratnike, R. N., 2005. Zinc in Health and Chronic Disease., J. Nutr Health Aging, 9 (1): pp. $45-51$.

Wellinghausen, N.; Jochle, W.; Reuter, S.; Flegel, W. A.; Grunert, A. and Kern , P., 1999. Zinc Status in Patients with a Lveolar Echinocoecosis is Related to Disease Progression . Parasite . Immunol. , 21 (5) : pp. 237 - 241. 